\title{
Bovine serum albumin adsorption onto hydroxyapatite and biphasic calcium phosphate ceramic granules
}

\author{
Inga Jurgelane, Armands Buss, Anna Vojevodova and Dagnija Loca \\ Institute of General Chemical Engineering, Faculty of Material Science and Applied Chemistry, Riga \\ Technical University, Latvia \\ inga.jurgelane@rtu.lv
}

\section{INTRODUCTION}

Hydroxyapatite (HAp), beta tricalcium phosphate $(\beta$-TCP) and biphasic calcium phosphate $(\mathrm{BCP})$ are calcium phosphate based ceramics and the most studied biomaterials for bone defect repair [1]. One of the main requirements for these biomaterials is to be bioactive. The bioactivity of calcium phosphate based biomaterials can be evaluated by adsorption of proteins [2]. The most abundant protein in the circulatory system is bovine serum albumin (BSA) therefore this protein is mostly used in vitro studies for bioactivity [3]. BSA sorption results onto HAp and BCP ceramic granules are presented.

\section{EXPERIMENTAL METHODS}

HAp and BCP were synthesized by wet precipitation method from calcium hydroxide and phosphoric acid. To identify the ratio of HAp and $\beta$-TCP phases X-ray powder diffraction (XRD) was used. The precipitate were filtered and used to form granules. The paste was pressed though $1.4 \mathrm{~mm}$ sieve, dried, sieved though $1.4 \mathrm{~mm}$ sieve, sintered at $1150^{\circ} \mathrm{C}$ for $2 \mathrm{~h}$ and sieved using vibrational sieves to gain granules with fraction $0.5-1 \mathrm{~mm}$. The obtained fraction was characterized with loose density and specific surface area by BET method. Protein solutions were prepared in simulated body fluid (SBF) and phosphate saline buffer (PBS) solution at $\mathrm{pH} 7.4$ by dissolution of BSA with concentration $2 \mathrm{mg} / \mathrm{ml}$. $0.1 \mathrm{~g}$ of granules were mixed with $8 \mathrm{ml}$ of BSA solution and incubated at $37^{\circ} \mathrm{C}$ with continual agitation for 5 minutes to 24 hours. The residue concentration was determined at $280 \mathrm{~nm}$ using UV-VIS spectrophotometer. All calibration solutions also were incubated at $37^{\circ} \mathrm{C}$ and measured each time together with the samples.

\section{RESULTS AND DISCUSSION}

The highest sorption capacity (mg BSA/1 g granules) showed sample with HAp/ $\beta$-TCP ratio $50 / 50$ but the lowest sorption showed sample $10 / 90$ in both SBF and PBS media. These results are related to the specific surface area (see Table 1). In SBF media the adsorbed BSA amount is more than 2 times higher than in PBS.

Table 1 Characteristics of the samples studied

\begin{tabular}{ccc}
$\begin{array}{c}\text { COMPOSITION } \\
\text { HAp/ } \beta \text {-TCP }\end{array}$ & $\begin{array}{c}\text { LOOSE } \\
\text { DENSITY, } \\
\mathrm{g} / \mathrm{ml}\end{array}$ & BET, $\mathrm{m}^{2} / \mathrm{g}$ \\
\hline $100 / 0$ & $1.19 \pm 0.01$ & $0.92 \pm 0.10$ \\
$80 / 20$ & $1.06 \pm 0.01$ & $0.80 \pm 0.07$ \\
$50 / 50$ & $0.99 \pm 0.01$ & $1.13 \pm 0.03$ \\
$30 / 70$ & $1.10 \pm 0.01$ & $0.80 \pm 0.04$ \\
$10 / 90$ & $1.23 \pm 0.02$ & $0.05 \pm 0.01$ \\
\hline
\end{tabular}

\section{CONCLUSION}

All calcium phosphate ceramic granules showed sorption properties towards BSA in both media. BSA sorption capacity correlates with the specific surface area.

\section{REFERENCES}

[1] Wang K. et al., Interface Focus (2012), 2:259-277

[2] Combes C. et al., Biomaterials (2002), 23:2817-2823

[3] Mavropoulos E. et al., Colloids Surface B (201), 83:1-9

\section{ACKNOWLEDGMENTS}

This work has been supported by the National Research Programme No.2014.10-4/VPP-3/21 "MultIfunctional Materials and composItes, photonicS and nanotechnology (IMIS2)" Project no.4 "Nanomaterials and nanotechnologies for medical applications". 